\title{
African Christian View on Morality of Abortion
}

\author{
Ron Macaulay ${ }^{1}$ \\ ${ }^{1}$ Global Theological Seminary, Accra, Ghana.
}

\begin{abstract}
There are several medical, ethical, theological, and personal sensitive questions on abortion a developing phenomenon across all racial groups. Admittedly, the debates over its morality and verdicts are complex. Notwithstanding the complexity and the numerous sensitive questions surrounding its morality, it has been observed that some women practice abortion regardless of their religious and cultural affiliations. Perhaps, there must have been a gap which may have been serving as grounds for the practice of abortion among women without considering the rights of the foetus. This study seeks to find out the rightness or wrongness of the phenomenon, viewed from African Christian perspective. The study blends ethical and theological methods and a qualitative technique in the analysis. The findings are that even though women have the rights to commit abortion, regardless of the rights of the foetus, they should exercise those rights and make the choice before conception, and not after. This is because once they conceive, the child has independent rights both before and after birth. The study recommends that pregnant women should not take it upon themselves to end the lives of the unborn. Those who are seeking abortion are to be encouraged to consider other options such as giving birth and giving out the babies for adoption. This work fills the gap between African Christian and secular views on the morality of abortion.
\end{abstract}

\section{Correspondence: Ron Macaulay Email: ronmacaulay14@yahoo. com}

\section{Publication History}

Received 25th August 2020, Accepted 29th October 2020, Published online 3rd November 2020.

Keywords: foetus, abortion, morality, murder.

(C) 2020 The Author(s). Published and Maintained by Noyam Publishers.

This is an open access article under the CCBY license (http://creativecommons.org/licenses/by/4.0/).

\section{INTRODUCTION}

Though there are divergent views on abortion, this work looks at the phenomenon from the perspective of where some people utilise external intervention to interfere with the reproductive process to destroy the foetus. As far as the morality of abortion, which has become a highly complex issue, is concerned, John Stott argues that, Christians cannot opt out of personal decision-making or public discussion on the topic "Abortion," merely because of its complexity. ${ }^{1}$

A number of very important ethical views come up in any discussion on this subject, both from the Western world and Africa. Just as the Western understanding of ethical issues has affected the ethical thinking of Christians in the West, so also has the African understanding of ethical issues affected the ethical thinking of Christians in Africa. This is because most African Christians believe that Christian morality must be grounded in God as revealed in the Scriptures. For this reason, they believe that the Scriptures are the arbiter in matters of morality, faith and practice. In order to make an explicit discussion, the study looks at some of the places of abortion as a phenomenon in African morality. Also, different views are shared on the phenomenon, such as the various types of abortion in general terms, the fundamental issue of personhood, the issue of women's right, abortion in African societies, and Christian views of abortion. Interestingly, though much ambiguity seems to surround the legitimacy of abortion; it calls for the attention of the African Christian views on the phenomenon.

\section{The Place of Abortion in African Morality}

Since child birth is an important event within many African societies, ethnic groups have socio-cultural practices that mark the child's major transition points, namely the time the child is conceived and when it enters the world through

\footnotetext{
John Stott, Decisive Issues Facing Christians Today (Michigan: Fleming H. Revell. Grand Rapids, 1990), 308.
} 
birth. Among Africans, when a woman becomes pregnant, it is the indication that a new member of that family is about to be born. The mother becomes, therefore, a special person and is treated with dignity by her neighbours. This special treatment starts before and continues after childbirth. There are instances where some husbands humorously put their ears on the stomach of the woman to listen to how the unborn baby leaps in the womb. This is because in some African societies, marriage is not fully recognised until the wife has given birth to a child. Kunhiyop asserted that infertility is seen among Africans as a negation of life, the destruction of the individual and the community. ${ }^{2}$

Pregnancy becomes, therefore, the final seal of marriage, the sign of complete integration of the woman into her husband's family. Unhappy is the woman who fails to get children, whatever other qualities she might possess, "her failure to bear children is worse than committing genocide." 3 The importance of children among Africans leads to the fact that, childless couples are despised among almost all the ethnic groups of Africa.

To a large degree, when a child is born, it is considered as a great blessing to the family. People who die through termination of pregnancies, in other words, abortion are not accorded normal funeral rites. Among some ethnic groups in Africa, rites are performed during pregnancy to protect the foetus or baby from witches. It is believed that witches feed on a foetus and destroy it. This superstitious belief is known as witchcraft. McKinney defines witchcraft as "an inherent power to exert supernatural influence over another person." Hence, in order to protect a pregnant woman, some items are processed into talisman to be worn around the waist or knees. Again, seven incision marks are given on the chin or face of the woman into which black powder is inserted to protect the foetus. This is because miscarriage is highly regretted when a married couple experience one. Also, women who are not married and yet commit abortions are not respected in society. This means that in African morality, whilst the foetus is highly regarded and protected because it is believed to be a living being, abortion is frowned upon and abhorred.

\section{The Different Types of Abortion}

Abortion is a medical operation, or some other means to end a pregnancy so that the baby is not born alive. It is used as a means to eliminate a foetus. Also, it is frequently seen as an appropriate method of birth control. The methods of abortion can be divided into two major categories, which are spontaneous abortion, and induced abortion. ${ }^{5}$

The ways spontaneous abortions occur are not usually thought of as abortions. It is because what characterises these classes of abortions is that, there is no outside interference, in other words, external intervention. ${ }^{6}$ There are two basic types of spontaneous abortions, which are monthly menstruation, and miscarriage. There are high numbers of cases where an egg is fertilised by sperm, but never implants in the uterus. Instead, it simply passes out of the woman's uterus as her monthly period. In this instance, the woman might not know that she was pregnant. ${ }^{7}$ In the case of miscarriage, "a developing foetus is expelled from the mother's body before the baby is able to live outside the womb."

Due to the nature of induced abortions, many people think of it as the only type when they hear people talk about abortion. This category of abortion is characterised by external intervention which interferes with the reproductive process with a view to terminating a pregnancy. There are several types of induced abortions of which Therapeutic Abortion (TA) is one. Therapeutic abortions are done to save the mother's life to the detriment of the foetus. ${ }^{9}$ Surgical therapeutic abortion is done using any of the following methods: Manual vacuum aspiration (MVA). In this case, a powerful instrument is inserted into the uterus where it tears the developing baby and the placenta apart, allowing them to be sucked out into a jar. According to Encarta dictionary, the placenta is "a vascular organ that develops inside the uterus of most pregnant mammals to supply food and oxygen to the foetus through the umbilical cord." It is expelled after birth. Another type is Dilation and Curettage (D\&C). In this process, "the woman's cervix is dilated and a sharp instrument is used to remove the placenta off the wall of the uterus," in the process cutting the baby to pieces. ${ }^{10}$ Lastly, Dilation and Evacuation (D\&E) is also performed. ${ }^{11}$ Due to the present scientific advancement of medicine, some of these abortions are not happening very often. Besides, there are illegal abortions that comprise practices that create hazardous circumstances during, or after an abortion. Elective abortion is another category of induced abortions.

There are cases where the mother's life is not threatened by the pregnancy, and the life of the child has not been faced with any permanent injury or damage, as to whether the child would become lame or a cripple. Thus, some of the reasons for this type of abortion are simply for the convenience of the parents, the control of family size, to reduce

\footnotetext{
Samuel Wage Kunhiyop, African Christian Ethics (Nairobi: Hippo Books, 2008), 195.

John S. Mbiti, African Religion and Philosophy (New Hampshire: Heineman Educational Books Inc., 1989),

Carol McKinney, The Bajju of Central Nigeria: A Case Study of Religious and Social Change (PhD Dissertation, Southern Methodist University, 1985), 59; Kunhiyop, African Christian Ethics, 377.

Kunhiyop, African Christian Ethics, 330-331.

John S. Feinberg and Paul D. Feinberg. Ethics for a Brave New World. Illinois: Crossway Books. A Division of Good News Publishers, 1993.

Kunhiyop, African Christian Ethics, 331.

James N. D. Anderson, Issues of Life and Death (Downers Grove, IL: InterVarsity Press, 1977), 78.

Chi Trib, The Waukegan News-Sun, June 6, 1990. In John S. Feinberg and Paul D. Feinberg, Ethics for a Brave New World, 1993.

Kunhiyop, African Christian Ethics, 333.

Nigel M. de S. Cameron and Pamela F. Sims, Abortion: The Crisis in Morals and Medicine (Leicester, England: Inter-Varsity, 1986), 53-56.
} 
physical or mental strain on the parents, or financial hardship on the family. Also, some families go at length to choose a gender specific child and abort those that they think are of the "wrong" sex. ${ }^{12}$

\section{The Fundamental Issue of Personhood}

The beginning of life, which is referred to as the beginning of personhood, in other words, when a human being is formed is the major argumentative issue in the abortion debate. There are two schools of thought known as pro-choice (pro-reproductive rights) and pro-life (anti-abortion) who contribute to abortion.

On one hand, pro-choice advocates often say that, no one can really testify to the fact that he or she knows when human life actually begins. To them, "that is a religious, philosophical or metaphysical matter. They argue that, it is impossible to know when life begins, therefore, when and whether to abort are decisions between the mother and her physician." ${ }^{13}$ Pro-choice adherents also believe that women have a right to have an abortion. They say that it is not merely the possession of life that makes someone human, but possession of a significant life. The issue here is about the quality of life. They argue that unless the foetus is happy, healthy, and able to do what human beings ought to do, it is not human. According to them, to be human, someone must be conscious of both external and internal events, be capable of self-motivated activity, have the ability to communicate about contents and topics, and have a self-concept and selfawareness. To those who accept this argument, no foetus can qualify as a person. The problem with this argument is that deformed babies and the invalid or infirmed can be put to death without any fear of being charged with murder. To elucidate the full picture, according to pro-choice position, a baby that is born blind and dumb, and the infirm who is unable to see and speak can be put to death just because they are unable to communicate.

Also, the pro-choice position argues that abortion should be done at any time because the foetus is "Subhuman." In that regard, they use the Bible to support their argument. The Bible passages used for this position are: Genesis 2:7 which declares that the first man "became a living being" only after God "breathed into his nostrils the breath of life." Hence, they posit that since breathing does not occur until birth, the unborn children are not human until they are born. They use Job 34:14-15, to argue that since life is connected with breath, there is no human life before birth. Again, they argue that Matthew 26:24 records Jesus' statement about Judas when he said, “....woe to that man who betrays the Son of Man! It would be better for him if he had not been born." The implication drawn from this is that human life begins at birth. Otherwise, Jesus should have said "it would be better for him if he had not been conceived." 14

In addition, pro-choice advocates quote and interpret Scriptures such as the following to support their position. According to them, a pregnant woman who is injured and aborts the foetus warrants financial compensation only (to her husband), suggesting that the foetus is a property, not a person (Exodus 21:22-25). In actual fact, the Scripture did not say "abort." It is clear that this Scripture is not about abortion, but about compensation if the woman gives birth to the child prematurely. For the fact that the text says "prematurely" does not mean the child is dead. Affirmatively, "if any mischief (harm, serious injury) follows, then thou shalt give life for life, eye for eye, tooth for tooth, hand for hand, foot for foot" (Exodus 21:23). This teaches about the sanctity of life and fair judgement - to limit the punishment to fit the crime.

Also, Elisha's prophecy for King Hazael said he would attack the Israelites, burn their cities, kill their young men with the sword, crush the heads of their babies and rip open their pregnant women (2 Kings 8:12). As far as God's justice is concerned, this Scripture explicitly described and also gave a clear picture of the severity of the judgement God was about to send on Israel by the hand of Hazael, which has nothing to do with abortion.

On the other hand, pro-life proponents argue, in actual fact that, they do know when human life begins. They argue that, human life is a scientific or biological question, which they are in a good position to provide answer to. To them, the embryo, in other words, foetus is alive. They justify their argument that, once a sperm produced by the sex organs of a male person, penetrates the egg and fertilises it, the cells begin to divide and produce exact copies of themselves. That is known as life. ${ }^{15}$ The cells replicate not just any life, but human life. Pro-life is opposed to abortion and uses this word to describe their opinion. Pro-life advocates are unable to understand why pro-choice advocates are insensitive to the baby's right to life. According to them, "if there is no right to kill a person after birth, then it is not right to kill one before birth." Due to the sanctity of life, abortion should never be done because babies are "fully human" and life must be considered over privacy. Pro-life advocates argue that, personhood begins at conception. According to them, "if the newly fertilised egg is examined under a microscope, one can determine that the Deoxyribonucleic Acid (DNA) strands are those of human beings. Moreover, it is argued that though the foetus is dependent upon the mother, he or she is an independent individual. ${ }^{16}$

\footnotetext{
2 Kerby Anderson, Christian Ethics in Plain Language (Nashville: Thomas Nelson, Inc., 2005), 39-40.

13 Laurence H. Tribe, Abortion: The Clash of Values (New York: W. W. Norton \& Co., 1990), 113-120.

4 Norman L. Geisler, Christian Ethics: Contemporary Issues and Options (Michigan: Baker Academic. Grand Rapids, 2010), 132-133.

Feinberg \& Feinberg, Ethics for a Brave New World.

Paul D. Feinberg, “The Morality of Abortion,” in Richard L. Ganz, ed., Thou Shalt Not Kill (New Rochelle, NY: Arlington House Publishers, 1978), 129-130.
} 


\section{The Issue of Women's Right}

It has been observed that, though in some countries, abortion as a phenomenon is an accepted practice where people express little opinion about its morality; it is not the same in some African countries, as far as Christian morality is concerned. Many in the West would argue that the mother has the right to do as she pleases with her body. If she wants to remove a foetus that is growing in her womb, no one should be able to prohibit her from doing so. This argument is rooted in the Western belief that individual rights trump community rights. ${ }^{17}$ Such individualistic thinking is alien to African traditional society. However, Africans are increasingly buying into this mind-set where a person does whatever he or she pleases. A girl who gets pregnant now makes her own decision to abort the baby if she does not want it.

If people are free to choose what to do with their pregnancies whether or not to abort it, the questions that come to mind are: Can people be morally responsible for the choice they make in life? Should one be blamed for making a choice since they have their rights or free will to do so? Unavoidably, in life one is faced with the decision of making a choice. The choice that one makes is dependent on a number of reasons. One of the reasons is that, since human beings are rational beings, some people may conclude that they have a right to a particular choice irrespective of their religious affiliation or culture. For instance, the reader of this article is free to either stop or continue reading it, even now; it is a choice. This could be a free will choice depending on the circumstances surrounding the situation. ${ }^{18}$ Now, with regard to abortion, the consequentialist may argue that, the woman has the rights to get rid of an unwanted pregnancy in order to have her freedom, because the end justifies the means. Nevertheless, the fundamental flaw in this argument is that "it fails to acknowledge that the baby does not actually belong to its mother or its father but to its maker, God." ${ }^{19}$

\section{Abortion in African Societies}

Abortion in indigenous African societies was not well documented in the past because of the few records that are available. This is because the many factors that lead to abortion were absent. A typical example is that there was no way of knowing whether a foetus was deformed or not. Secondly, when a man and a woman had illegal sexual intercourse and the woman became pregnant, it was those responsible for the pregnancy who were punished, and not the unborn child. In a similar way, those who committed incest were severely punished, and also made to undergo ritual ceremonies. They were either banished, or made to undergo rigorous ritual cleansing. ${ }^{20}$

Also, among Africans, children were not solely the responsibility of their biological mothers and fathers, but belonged to all in the community. If a child's parent could not care for it for some reasons, uncles, aunts, grandfathers, grandmothers, cousins, brothers and sisters, and stepsisters would take over. Nevertheless, some currently argue that it is better for a mother to abort an unwanted pregnancy than to bring an unwanted child into the world. Also, it is possible that the strongest motivation for abortion in Africa is poverty. Hence it is not that a child is unwanted but that parents who are enduring unemployment, and desperately suffering see no way of providing for it. They choose abortion over bringing a child into a home where it will be undernourished, undereducated and doomed to a life of gross poverty.

However, this argument will certainly not have been the case in traditional African societies, where no child was dismissed as a "bastard," "illegitimate" or neglected, because children were seen as belonging to all. Today, however, community ethics are being eroded, and babies are sometimes being rejected and left to die. Unwanted children roam the major cities in Africa, begging for money or food. This is the result of their parents' refusal to accept the responsibility that goes with sexual relationships. Now, what is the view of the African Christian on the issue of abortion?

\section{African Christian View of Abortion}

What the African Christian view seeks to do here is to juxtapose the positions of the pro-choice and pro-life, as far as abortion is concerned. According to Macaulay, while God's Word may not cover every situation man faces in life, its principles provide standards where there are no explicit instructions. Hence, this segment of the study is largely based on the guidance of the Bible and reason. ${ }^{21}$

Among African Christians, biblical considerations are critical for their discussion on abortion. Fascinatingly, there is no explicit teaching on abortion in the Bible. So the case must be built by looking at what the Bible has to say about related ethical matters. Several crucial factors come into play whenever the topic of abortion is raised among African Christians. One of those factors is the debatable issue of when human life actually begins.

Many African Christians have a very strong belief on the immorality of abortion, and therefore, have a contrary view to the pro-choice position that life begins at conception. Hence, they are fond of referring to biblical passages to influence people's opinion about God's omniscience, and also refer to those that reflect God's future plans for unborn

\footnotetext{
Judith Jarvis Thompson, “A Defense of Abortion,” Phil Pub Affairs 1 (1971): 47- 66.

Ron Macaulay, Redeeming the Master Plan: An Ethical Study on Marital and Sexual Issues. $2^{\text {nd }}$ Ed. (Accra: Gusfa Ventures, 2019$), 222$.

Kunhiyop, African Christian Ethics, 337.

Mbiti, "Religion and Philosophy", in Kunhiyop, African Christian Ethics, 331.

Macaulay, Redeeming the Master Plan, 220.
} 
children. For example, Psalm 139:13-16 provides a glimpse of the personhood and worth of the unborn child. The "unformed baby" to which the psalmist refers to is the embryo or foetus. The psalmist explicitly indicated that, "My flesh was made by you, and my parts joined together in my mother's body" (Psalm 139:13). God created and supervised the psalmist in his unborn state, in fact, even before he was conceived. ${ }^{22}$ Again, in Psalm 51:5, the psalmist said, "Surely I was sinful at birth, sinful from the time my mother conceived me." The psalmist also identified that he was already a moral being, in that, even in his embryological or developing state in the womb, the moral law was inscribed within his being. He already had a soul that was affected by the sin which tainted all human beings. Also, God told the prophet Jeremiah that, "I knew you before I formed you in your mother's womb. Before you were born I set you apart and appointed you as my spokesman to the world" (Jeremiah 1:5). Furthermore, the angel of the Lord predicted the birth of John the Baptist and said, "For he will be great in the sight of the Lord, and shall drink neither wine nor strong drink. He will also be filled with the Holy Spirit, even from his mother's womb" (Luke 1:15). The Scripture established that, the baby made a sudden move inside the womb of Elizabeth and "in a loud voice (Elizabeth) exclaimed (to Mary): 'Blessed are you among women, and blessed is the child you will bear! ... As soon as the sound of your greeting reached my ears, the baby in my womb leaped for joy"' (Luke 1:41 and 44). ${ }^{23}$ Considering all the above Scriptures, there can thus be no doubt that an unborn child is fully human. Also, there are instances where God declares miscarriage (the death of unborn children) as part of his curse on those who disobey him (Hosea 9:14), and those who obey him are to be blessed with live births (Exodus 23:26).

In addition to the above assertions, there are a number of prophecies that predict that, certain women would conceive and give birth to special children. Such assurances were made to Sarah in Genesis 18:9-14; and also in Judges 13:3-5 which records Samson's mother's conception. Mary the mother of Jesus also was promised a son in Luke 1:2638, and many others. These predictions have informed the decision of those who believe in Scripture to come to the conclusion that, every child has a God-ordained destiny, and fits into God's overall plan for humanity. Abortion, therefore, is not merely the removal of a not-yet-viable embryo, but rather the loss of a very real person as well as all that, that unique child of God might have done in his or her lifetime. In this regard, Macaulay posits that, Christians are expected to understand the Bible and conduct their lives within the tenets of ethical principles as taught by Jesus Christ, which substantiate their claim that they are his followers. This concept operates within the principles of Christian deontology, which provide the explanation that an action is morally obligatory as a moral command which either mandates it or forbids it. ${ }^{24}$

Hence, the inference drawn is that abortion should be discouraged, especially, among African Christians and other Bible believing Christian deontologists. A Christian deontologist is obliged to obey the rules of God, because they are morally absolute. By virtue of God's moral character, the African "Christian can absolutely believe that since God made the rules, it is simply their duty to obey them." 25

Some of the reasons why a large number of abortions are performed among African Christians these days are when women cannot face the social stigma associated with untimely pregnancies. Also, prospective couples who are preparing to marry in a church may insist that the woman take pregnancy test before the wedding. Where the woman is found to be pregnant, they may resort to abortion. The most disgraceful one is when an unmarried daughter of a pastor gets pregnant, or his son impregnates a lady. The shame is deeply felt because pastors' families are expected to set a morally good example to the community. ${ }^{26}$

Cohen posits that there are some who are of the view that law and ethics can be separated, as if law were not a matter of interpreting what morality is about. Every law is the result of a decision about good and bad, right and wrong. "It is a pretty safe rule that whenever a judge says, 'This is a court of law', and then goes on to say that he cannot be guided by ethical/moral or theological considerations, he is actually being guided by moral or theological considerations without knowing it."27 There is no arbitrary moral decision which has nothing to do with ethical principles of good and bad, right and wrong. Since one takes a position of right and wrong, there must be a moral basis of such a decision. This is because the judgement must rest within some fundamental tenets of ethical or moral principles by which one makes a moral claim, or gives the verdict of right and wrong.

In actuality, some forms of immoral behaviours are related to criminal law, such as adultery, bigamy, rape, prostitution, and incest. These are all sexual issues, which have something to do with morality and theology. If that is the case, then, on which grounds should abortion which is the process of destroying a foetus - the product of sex - be left out? However, if it is not the case, then, criminal laws need a complete overhauling - a system or method to improve

\footnotetext{
Stott, Decisive Issues Facing Christians Today, 315.

Stott, Decisive Issues Facing Christians Today, 317.

Macaulay, Redeeming the Master Plan, 248.

Norman L. Geisler, Christian Ethics: Contemporary Issues and Options, 74.

Kunhiyop, African Christian Ethics, 332.

Felix S. Cohen, “Judicial Ethics," Ohio State Law Journal 12 (1951)
} 
it - where murder occurs as a result of sex.

Medical views drawn by Christians on abortion are that, in exception of problematic deformity of a foetus, abortions are clearly wrong because abortion is murder, it devalues human life, and it destroys family life. Abortions are not accidental; they are deliberate acts intended to destroy the unborn baby. Though beneficence (good or charitable act) requires a nurse to do what is morally acceptable, an ethical decision based upon charitable acts often may be complex, where observing acceptable ethical principles for the patient may cause some physical damages to the foetus. On the other hand, non-maleficence (non-harmful or evil act) requires that the action of a nurse should not do anything that is harmful to either the woman or the foetus. This could mean that a nurse should not assist in a medical treatment or operation that will lead to the death of the foetus.

It has been observed that, within the discipline of professional nursing, there are pro-life and pro-choice nurses who may either accept or refuse to help in abortion operations. Though most government hospitals undertake the procedure of abortion, it comes with certain restrictions. It does not mean that if one walks into any health centre one would have an abortion done. There are options and trained counsellors who will take the individual through the options.

While it is difficult, and perhaps impossible, to convince a pro-choice of the personhood of the foetus from a purely ethical point of view, it still makes sense to demand that human life should not be arbitrarily terminated, particularly, when less drastic solutions exist. This is because having been conceived, the foetus has no choice but to grow, just as it had no choice in its conception. The same is not true of the mother, who has at least three alternatives of planning their families other than abortion. Firstly, she can exercise initial will power by abstinence, which is grossly out of fashion today. Even though abstinence in marriage is a natural method, absolute abstinence seems to be contrary to Scripture. This is because according to Paul's statement in 1 Corinthians 7:5, married couples should not deprive one another, and therefore, cannot be a morally justifiable means of birth control. Secondly, she has the option to use contraception to prevent the unwanted child. Finally, after being delivered of the child, the mother can allow the living but unwanted infant to be put up for adoption. Adoption is an act of leaving one's natural family and entering into the privileges and responsibilities of another. It is also the legal act of taking someone mostly a child or children of another person to be taken care of as your own child or children. ${ }^{28}$ The type of adoption you choose depends on the laws of your state. In most parts of Africa, adoption is also done through family agreement only. So far as the family of the child comes together and agreed to hand over the child, it is recognised.

While this approach does not entirely resolve the confrontation between the two sides in the debate, it does make it clear that "it is the foetus who is the innocent victim. The mother, who is in control, at least in some human sense, should take the necessary precautions to prevent the conception and subsequent destruction of it." ${ }^{29}$ Since the consequences of facing difficult situations are not always in man's control, and things do not always turnout as expected, ideally, man's motives are in his/her control. ${ }^{30}$

Whether it is right to commit abortion in cases of rape and incest, the initial argument is that, it is never right to do evil, in other words, to commit abortion to achieve good. Put another way, two wrongs do not make a right. It is argued that while rape and incest are horrible acts, so is abortion. While rape and incest are acts of violence against the mother, so is abortion to the foetus.

\section{CONCLUSION}

Since the study seeks to ascertain the position of the African Christian on the morality of abortion, a conclusion must be drawn that the pro-life position is morally acceptable because it is in accordance with the African Christian view that abortion is immoral. As a result, the study shows that induced abortions in general are immoral. Given the large number of abortions, the study concludes that an unwanted child by its mother should not necessarily be aborted, because there are many options to choose from, such as adoption, abstinence and the use of contraceptive. This will go a long way to avoid complications that could lead to death of pregnant women and other life-time consequences.

As argued, abortion is not free of problems or illness that happens after it has been performed. Also, when someone is raped or involved in incest and tries to escape the stigma that goes with it by committing abortion, it makes the innocent baby a victim of the crime as well. While the woman is already a victim of rape or incest and tries to commit abortion; the act only adds another problem to the one she already has.

Sometimes economic hardship seems to be the cause of many abortions. Though economic issues are factors, there are views that it is never right to commit abortion in order to alleviate suffering. This is because abortion is considered to be murder. Having been conceived, the foetus has no choice but to grow, since it has no choice in its conception. Hence, the inference drawn is that abortion should be discouraged, especially, among African Christians and other Bible believing Christian deontologists whose duties are to obey the rules of a moral God. To the Christian, Jesus Christ must

\footnotetext{
Cambridge Advance Learners' Dictionary, $3^{\text {rd }}$ Edition.

29 Feinberg and Feinberg, Ethics for a Brave New World, 145.

Barbara Mackinnon, Ethics: Theory and Contemporary Issues, $5^{\text {th }}$ ed. (Belmont: Thomson Wadsworth, 2007$), 73$.
} 
always be Lord and ought to be obeyed in even difficult situations. Finally, Christians should not forget that ".... takers of life, those who commit the sins of the flesh, and all those who are false, will have their part in the sea of ever-burning fire which is the second death" (Revelation 21:8).

\section{ABOUT AUTHOR}

Ron Macaulay holds a Master of Philosophy in Study of Religions Degree from the University of Ghana, Legon. He is a Minister of the Global Evangelical Church, a Lecturer and the Dean of Students at Global Theological Seminary, Accra, Ghana.

\section{BIBLIOGRAPHY}

Anderson, James N. D. Issues of Life and Death. Downers Grove, IL: InterVarsity Press, 1977.

Anderson, Kerby. Christian Ethics in Plain Language. Nashville: Thomas Nelson, Inc., 2005.

Cohen, Felix S. “Judicial Ethics," Ohio State Law Journal 12 (1951).

Feinberg, John S. and Paul D. Feinberg. Ethics for a Brave New World. Wheaton, Illinois: Crossway Books, 1993.

Feinberg, Paul D. "The Morality of Abortion," in Richard L. Ganz, ed., Thou Shalt Not Kill. New Rochelle, NY:

Arlington House Publishers, 1978.

Geisler, Norman L. Christian Ethics: Contemporary Issues and Options. Michigan: Baker Academic. Grand Rapids,2010.

Kunhiyop, Samuel Wage. African Christian Ethics. Nairobi: Hippo Books, 2008.

Macaulay, Ron. Redeeming the Master Plan: An Ethical Study on Marital and Sexual Issues. $2^{\text {nd }}$ ed. Accra: Gusfa Ventures, 2019.

Mackinnon, Barbara. Ethics: Theory and Contemporary Issues, $5^{\text {th }}$ ed. Belmont: Thomson Wadsworth, 2007.

Mbiti, John S. African Religion and Philosophy. New Hampshire: Heineman Educational Books Inc., 1989.

McKinney, Carol. The Bajju of Central Nigeria: A Case Study of Religious and Social Change (PhD Dissertation, Southern Methodist University, 1985), 59. In Kunhiyop, African Christian Ethics.

Nigel M. de S. Cameron and Pamela F. Sims, Abortion: The Crisis in Morals and Medicine. Leicester, England: Inter-Varsity, 1986.

Stott, John. Decisive Issues Facing Christians Today. Michigan: Fleming H. Revell. Grand Rapids, 1990.

Thompson, Judith Jarvis. "A Defense of Abortion," Phil Pub Affairs 1, 1971.

Tribe, Laurence H. Abortion: The Clash of Values. New York: W. W. Norton \& Co., 1990. 